\title{
Activated Lymphocyte
}

National Cancer Institute

\section{Source}

National Cancer Institute. Activated Lymphocyte. NCI Thesaurus. Code C32049.

A white blood cell that, after being in contact with an antigen, rearranges its DNA to defend ag ainst that one specific type of antigen. After activation, it can then proliferate and differentiate into memory cells, antibody-secreting cells or plasma cells. 